\title{
Foreign Terrorist Fighters from the North Caucasus: Understanding Islamic State Influence in the Region
}

\section{Dasha Nicolson}

\begin{abstract}
At the height of the influence of the 'Islamic State' in Syria, it involved in its ranks approximately 30,000 foreign fighters, with about a quarter of them coming form Russia (Chechnya and Dagestan) and the former Soviet Union. This article looks into the phenomenon of North Caucasian foreign terrorist fighters and its implications for security in North Caucasus, the Russian Federation and world-wide. The numbers of fighters returning from Syria to the region are not exactly known. Yet, upon returning home, the first wave of foreign fighters has managed to secure and build upon their reputations and expand their experience, skills and networks, establishing different jamaats and, in one instance, a 'jihadist private military company.' Given the opportunity, the second wave will most likely fight in the Caucasus, but if unable to return home they may be motivated to strike elsewhere.
\end{abstract}

Keywords: Russian, North Caucasus, Islamic State, foreign terrorist fighters, FTFs, antiterrorist legislation, counter-terrorist operations.

We are ashamed that we are going to Syria at a time when the Caucasus is still occupied, but young people are returning here once they've undergone a training course.

- BBC source, 'close' to Chechen boeviki

\section{Introduction}

In September 2014, the United Nations Security Council unanimously adopted resolution 2178 concerning the "acute and growing" threat posed by foreign terrorist fighters (FTFs). These individuals are defined as those "who travel to a State other than their States of residence or nationality for the purpose of the 
perpetration, planning, or preparation of, or participation in, terrorist acts or the providing or receiving of terrorist training, including in connection with armed conflict." ${ }^{1}$ FTFs affect the dynamic of conflict - its intractability, duration and intensity and, furthermore, pose a threat to their "States of origin, transit, destination, and neighboring zones of armed conflict in which they are active."2 Since the eruption of the civil war in Syria, and especially after June 2014 with the proclamation of the 'caliphate,' thousands of aspiring fighters from different regions have traveled to Iraq and Syria to join the Islamic State (IS) or other violent extremist groups. ${ }^{3}$ According to a report published by The Soufan Group in December 2015, the number of foreign fighters in Syria had reached approximately 30,000 , with individuals from over 100 countries. ${ }^{4}$ In 2015, the top three FTF nationalities were Tunisian (6,000), Saudi Arabian (2,500), and Russian (2,300), while there were approximately 4,700 fighters from the Former Soviet Republics. ${ }^{5}$ In October 2015, Russian President Vladimir Putin stated that around 5,000 to 7,000 fighters from Russia and the former Soviet Union (FSU) had traveled to Syria to join IS. ${ }^{6}$ The majority of these fighters are from the North Caucasus (Chechnya and Dagestan), with others from Azerbaijan and Georgia as well as Central Asia - Kazakhstan, Kyrgyzstan, Tajikistan, Turkmenistan, and Uzbekistan. Together they share not only the ability to speak Russian, but also a heritage of grievances stemming from the Afghan-Soviet and the post-Soviet conflicts. This article attempts to look into the phenomenon of North Caucasian FTFs and its implications for security in North Caucasus, the Russian Federation and worldwide. In doing so, the motivations of North Caucasian FTFs, the groups that they fight for, and links to the domestic terrorist situation will be considered.

By 2017, the total numbers of FTFs in Syria and Iraq has fallen, both due to losses on the battlefield and to the decreased flow of foreign fighters to the conflict. For example, according to INTERPOL, in 2016 the number of FTFs deemed to be in the region amounted to $15,000 .{ }^{7}$ Among other factors, this reduction in mobilization of FTFs is attributed to increased control measures put in place by UN Member States, the military pressure brought to bear upon the groups and

1 Resolution 2178 (2014), adopted by the UN Security Council at its 7272nd meeting, on September 24, 2014, S/RES/2178 (2014), http://www.un.org/en/ga/search/view_ doc.asp?symbol=S/RES/2178\%20(2014).

2 UN SC Resolution 2178.

3 Global Coalition, Foreign Terrorist Fighters - Trends and Dynamics, March 3, 2017, http://theglobalcoalition.org/en/foreign-terrorist-fighters-trends-and-dynamics.

4 The Soufan Group, Foreign Fighters. An Updated Assessment of the Flow of Foreign Fighters into Syria and Iraq, December 2015, http://soufangroup.com/wp-content/ uploads/2015/12/TSG_ForeignFightersUpdate3.pdf.

5 The Soufan Group, Foreign Fighters.

6 The Soufan Group, Foreign Fighters.

7 Tanya Mehra, "Foreign Terrorist Fighters: Trends, Dynamics and Policy Responses," ICCT Policy Brief (The Hague: International Center for Counter-Terrorism, December 2016), https://icct.nl/wp-content/uploads/2016/12/ICCT-Mehra-FTF-Dec2016-1.pdf. 
IS's "financial decline." The organization's vital sources of income are tied to its' territory: taxes and fees; oil; looting, confiscations and fines. ${ }^{8}$ Loss of territory and subsequent operation on "crisis budget" have caused the increase in desertion rates, difficulties in recruitment, and the growth of internal corruption and theft. ${ }^{9}$ Furthermore, as a result, the FTFs are suffering from low morale, many of them "are packing it in" and "want to defect." ${ }^{10}$ Of course, it is not only the decreased inflow of FTFs that has contributed to the fall in total numbers, but also the 'reverse flow' - FTFs returning to their home regions or moving to a third State. For example, by December 2016 approximately $30 \%$ of European FTFs were thought to have returned to their home countries. ${ }^{11}$ In view of this, the (overall) high number of North Caucasian FTFs involved in the conflict is a matter of concern. Will these FTFs return to their home regions with peaceful purposes or malicious intentions? Will they choose to stay in the conflict area and perhaps join other terrorist organizations as IS comes under increasing pressure? Or will they move to a third State, or reallocate and participate in a different conflict? Terrorism scholars Clarke and Amarasingham predict several options for transnational terrorists. The 'hardcore' FTFs of IS may stay in Syria and Iraq. ${ }^{12}$ Some could seek to join an "underground resistance of an ISIS, 2.0," which may, with time, form a covert terrorist organization. ${ }^{13}$ Others may change allegiances between the groups on the ground, and eventually seek rapprochement with alQaeda. Other FTFs who are prevented from travelling to their countries of origin-the 'independent', the "free agents" - could form "a cohort of stateless jihadists" and travel to a third state in the name of jihad. ${ }^{14}$ Finally, the FTFs who

8 Stefan Heißner, Peter R. Neumann, John Holland-McCowan, and Rajan Basra, Caliphate in Decline: An Estimate of Islamic State's Financial Fortunes (London: King's College, International Center for the Study of Radicalization and Political Violence, 2017), https://icsr.info/wp-content/uploads/2017/02/ICSR-Report-Caliphate-in-Decline-AnEstimate-of-Islamic-States-Financial-Fortunes.pdf.

9 Kairat Umarov, "Letter dated 11 January 2017 from the Chair of the Security Council Committee pursuant to resolutions 1267 (1999), 1989 (2011) and 2253 (2015) concerning Islamic State in Iraq and the Levant (Da'esh), Al-Qaida and associated individuals, groups, undertakings and entities addressed to the President of the Security Council," S/2017/35, UN Security Council, January 13, 2017, https://documents-ddsny.un.org/doc/UNDOC/GEN/N17/000/13/pdf/N1700013.pdf.

10 Paul Wood, "The Truth About Islamic State: It's in Crisis!" The Spectator, January 9, 2016, https://www.spectator.co.uk/2016/01/the-truth-about-islamic-state-its-in-crisis; Martin Chulov, "Losing Ground, Fighters and Morale - Is It All Over for ISIS?" The Guardian, September 7, 2016, www.theguardian.com/world/2016/sep/07/losingground-fighter-morale-is-it-all-over-for-isis-syria-turkey.

11 Mehra, "Foreign Terrorist Fighters: Trends, Dynamics and Policy Responses."

12 Colin P. Clarke and Amarnath Amarasingham, "Where do ISIS Fighters Go When the Caliphate Falls? They Have Options," The Atlantic Daily, March 6, 2017, https://www.theatlantic.com/international/archive/2017/03/isis-foreign-fighterjihad-syria-iraq/518313/.

13 Clarke and Amarasingham, "Where do ISIS Fighters Go When the Caliphate Falls?"

14 Clarke and Amarasingham, "Where do ISIS Fighters Go When the Caliphate Falls?" 
return to their home countries could be either the "disillusioned," the "disengaged but not disillusioned," or the "operational."15

North Caucasian FTFs are members of the much-fractured opposition to the Syrian government forces. The majority is in IS ranks, others are with al-Nusra, and the rest are part of numerous factions on the battlefield. Many of the North Caucasian FTFs have previous combat experience-for example, in Afghanistan, in Georgia, in Chechnya and Dagestan-and have reputations as fierce fighters. In fact, 'Chechen' fighters (and North Caucasians, generally) seem to be perceived as 'elite fighters,' worthy of respect. ${ }^{16}$ Such a reputation for violence seems to have been established in part by such individuals as Abu Omar alShishani (Tarkhan Batirashvili - now likely deceased as of 2016). Omar (Tarkhan) was from a village in the Pankisi Gorge that lies close to the Georgian-Chechen border. He was born to a Georgian father and an ethnic Chechen (Kist) mother and served for an intelligence unit of the Georgian army until he contracted tuberculosis. In 2010, he went to jail for weapons possession. His older brother, Tamaz, fought in the Chechen wars, and also subsequently joined IS. Omar became a prominent figure of the opposition, commanding powerful battalions such as the Jaysh al-Muhajirin wal-Ansar (Army of the Emigrants and Helpers) in 2013. Later on, in the year Omar al-Shishani became the northern commander for IS, leader of a Chechen and North Caucasian battalion within IS, and leader of special IS battalions. ${ }^{17}$ Generally, North Caucasian FTFs are concentrated in northern Syria - in Latakia and Idlib Provinces, Aleppo, and in the Turkish-Syrian border regions of Ras al-Ayn and Tal Abyad. ${ }^{18}$

Considering the high number of individuals involved as well as the history of conflict in the region, North Caucasian FTFs are likely to constitute a long-term security threat. It is also important to examine their motivations for fighting, the factions/organizations that they fight for, the extent of the influence of pro-jihadist propaganda and certain distinguishing characteristics (such as previous combat experience, ties to other terrorist organizations, etc.).

\section{Motivations to Fight in Syria}

Without doubt, the motivations of North Caucasian FTFs - as of those from other regions-are varied. However, one of the most important common motivations, distinguishing this group of individuals, is that the civil war in Syria provides an

15 Clarke and Amarasingham, "Where do ISIS Fighters Go When the Caliphate Falls?"

16 Joanna Paraszczuk, "IS's Abu Waheeb Really Liked North Caucasians' \& Notes on Circassians and Shishanis," From Chechnya to Syria, October 21, 2016, http://www.chechensinsyria.com/?p=25267.

17 "Natives from the Caucasians in the Ranks of IS (ISIS)," Kavkazsky Uzel [Caucasian Knot], February 21, 2017, http://www.kavkaz-uzel.eu/articles/251513.

18 Emil Souleimanov and Megan Ouellette, "The Participation of North Caucasian Jihadists in the Syrian Civil War and its Security Implications," Rubin Center, February 22, 2015, www.rubincenter.org/2015/02/the-participation-of-north-caucasianjihadists-in-the-syrian-civil-war-and-its-security-implications. 
alternative battleground for fighting against the Russian state. ${ }^{19}$ The conflict in North Caucasus, and especially in Chechnya, has a long history and revolves around the issue of gaining independence from the central government. This fight can be traced back to Imperial Russia and includes the two more recent bloody Russo-Chechen Wars as well as instabilities within the region. The protracted state of conflict (and official attempts at its normalization) produced and left grave societal issues and a heritage of immense grievances. These are the fuel for the North Caucasian resistance, for militants and extremists. However, insurgents or militants are left with a very limited ability to 'carry out the fight' in the region. For example, in Chechnya this is due to the pro-Kremlin government under former rebel Ramzan Kadyrov. The inability to 'carry out the fight' in the North Caucasus, in combination with Moscow's support for the Assad regime, serve as push-factors to join the fight in Syria. As Omar Shishani openly acknowledged in an interview that was re-published by EA Worldview in December 2013, the 'Caucasus Emirate' (CE) had 'sent in' fighters to Syria for the purpose of training. The aim was that they would then return 'experienced' to fight against Russia in the North Caucasus. In other interviews, Shishani mentions the wish to "weaken one of al-Assad's key allies" (i.e. Russia), and notes that "jihad against the Russians and their Baathist ally" was one of his primary motivations for fighting in Syria. ${ }^{20}$

On a side-note, the counter-terrorist operations (CTOs) carried out by Russian governmental and Special Forces and their consequences sometimes leave individuals with no choice but to leave the region, and establish themselves elsewhere. ${ }^{21}$ For example, this was the case for Abdulkadyrov - "who fought here in the forest" - from Dagestan: he was hunted by local law enforcement and militants, and in order to escape from both, left to fight in Syria. ${ }^{22}$ Before the 2014 Sochi Olympics, Turkey had also become a popular destination for both jihadists

19 Dmitry Shlapentokh, "The North Caucasian Resistance and the Syrian Crisis," Insight 83 (Singapore: Middle East Institute, National University of Singapore, 3 December 2012), https://mei.nus.edu.sg/publication/insight-83-the-north-caucasian-resistanceand-the-syrian-crisis/.

20 Jack Moore, "The Ginger Jihadist of Mosul: Omar Shishani the Chechen 'General'," International Business Times, June 24, 2014, http://www.ibtimes.co.uk/gingerjihadist-mosul-omar-al-shishani-chechen-general-1452232. See also Thomas Grove and Mariam Karouny,"Militants from Russia's North Caucasus join "Jihad" in Syria," Reuters, March 6, 2013, http://www.reuters.com/article/us-syria-crisis-russiamilitants-idUSBRE9251BT20130306; and Erin McClam, "Rising Star of ISIS Has Chechen Background and Fierce Reputation," RMSMC blog, July 2, 2014, https://rmsmcblog.wordpress.com/2014/07/11/more-on-omar-al-shishani-part-ii.

21 Elena Milashina, "Caliphate? A Bait for Fools!" Novaya Gazeta, July 29, 2015 (in Russian), www.novayagazeta.ru/articles/2015/07/29/65056-171-halifat-primanka-dlyadurakov-187. Milashina investigated the town of Novosasitli in the Khasavyurt district of Dagestan. In her article, she includes descriptions of several individuals who had left to fight in Syria.

22 Milashina, "Caliphate? A Bait for Fools!" 
transiting to Syria and the peaceful conservative Muslim families. ${ }^{23}$ Also, in 2016 'thousands of Chechens' travelled to Germany through Poland, in order to claim asylum. ${ }^{24}$ In June 2016, the number of Russians claiming asylum in Germany amounted to 1,835 , reportedly $90 \%$ of them were Chechen; and from the 6,100 who applied in Poland - $94 \%$ were from North Caucasus. ${ }^{25}$ According to head of the Brandenburg central registration office for foreigners, Frank Nürnberger, a similar surge had occurred in 2013, with a decline in 2014, and an increase in $2016 .{ }^{26}$

Of course, another prominent motivational factor is religion. Just as during the Chechen/Dagestani/Ingush resistance when religion served as a force to attract foreign fighters to Chechnya, so has religion been used as a unifying force by North Caucasians fighting in Syria. Many young men had been drawn to 'join the Syrian jihad' ${ }^{27}$ and convinced that it is their duty to take up arms. For one, they regard the Alawite (heterodox sect of Shi'i Islam) Assad regime as 'not truly Muslim' and 'infidel.' ${ }^{28}$ Second, the regime is perceived as 'Russia's key ally' in the Middle East. So, it is not only an opportunity for jihad, but also a duty of Russian-speaking Muslims to join their oppressed brothers in Syria. ${ }^{29}$ Most of North Caucasian FTFs are salafist. Others exhibit 'Sunni solidarity' in response to images and propaganda of Sunni Muslims injured/tortured/killed by the 'infidel' Alawi regime. ${ }^{30}$ Thus, the battleground in Syria presents North Caucasian FTFs with the chance to fight both the Russian government and its interests, and to fight the enemies of Islam worldwide. ${ }^{31}$

Furthermore, by participating in the Syrian civil war, inexperienced FTFs may obtain combat experience and establish connections - and engage in domestic insurgency or terrorist activities upon their return home. In addition, participa-

23 International Crisis Group, "The North Caucasus Insurgency \& Syria: An Exported Jihad?" Europe Report no. 238, March 16, 2016, https://www.crisisgroup.org/europecentral-asia/caucasus/north-caucasus/north-caucasus-insurgency-and-syriaexported-jihad.

24 Alix Culbertson, "Thousands of Chechens Slipping Through Unmanned Border in Latest German Migrant Crisis," Express, August 24, 2016, http://www.express.co.uk/ news/world/703337/Chechen-migrants-unmanned-German-border-Poland.

25 Janosch Delcker, "Germany's New Problem Border: Poland," Politico, August 24, 2016, http://www.politico.eu/article/police-officials-concerned-about-migrants-crossinggerman-polish-border-terrorism-migration.

26 Delcker, "Germany's New Problem Border: Poland."

27 Emil A. Souleimanov, "Globalizing Jihad? North Caucasians in the Syrian Civil War," Middle East Policy 21, no. 3 (Fall 2014), http://www.mepc.org/globalizing-jihad-northcaucasians-syrian-civil-war (21 August 2017).

28 Shlapentokh, "The North Caucasian Resistance and the Syrian Crisis."

29 Souleimanov and Ouellette, "The Participation of North Caucasian Jihadists in the Syrian Civil War and its Security Implications."

30 Souleimanov and Ouellette, "The Participation of North Caucasian Jihadists in the Syrian Civil War and its Security Implications."

31 Souleimanov, "Globalizing Jihad? North Caucasians in the Syrian Civil War." 
tion in the conflict may offer an opportunity for identity reconstruction - by stepping out from a life of poverty and unemployment, where "one has nothing left," to fighting for "a brotherhood in arms" and for "a noble" cause. ${ }^{32}$

The battle ground in Syria demonstrates the rise of a 'jihadist international,' as Mark Galeotti refers to the phenomenon, with fighters willing to travel from one conflict zone to another in the name of violent jihad, regardless of whether they have any personal connection to the conflict or not. ${ }^{33}$ First, this can be seen through the presence of numerous factions comprised of North Caucasians and individuals from Central Asia in Syria and Iraq (independent or al-Nusra affiliated). Second, in the case of some North Caucasian FTFs, this can be seen through the change of alliance among the different armed groups operating in the region, primarily fueled by the motivation to fight in the opposition to the alAssad regime in order to fight Russia. One example is Omar Shishani, who eventually ended up in IS ranks. Third, some of the prominent individuals have a history of participation in previous conflicts. The phenomenon, however, is not new - during the Chechen Wars, foreign warlords (Saudi-born Ibn Khattab, Abu Omar al-Saif, among them) established their commands in the North Caucasus. The term, 'jihadist international' then, can be used as a classification of FTFs, denoting those that are potentially more dangerous for global civil society because of higher commitment, greater (potential/future) experience, and the continued readiness to fight regardless of a personal connection to a given conflict.

Some scholars, for example Ratelle, argue that North Caucasian fighters can be divided into two waves: those that travelled to Syria in 2011-2013 because they could not fight in their home region, and those who traveled to Syria in 2014-2017 because they 'openly decided' not to fight in the North Caucasus and "to join an international jihadist front." ${ }^{34}$ The contestation between Imarat Kavkaz (Caucasus Emirate) and the Islamic State can, to some extent, explain this dynamic.

\section{Imarat Kavkaz vs Islamic State}

Imarat Kavkaz (IK, also known as the Caucasus Emirate, or CE) is a self-proclaimed separatist group which aspires to establish its own Islamic State within the North Caucasus. ${ }^{35}$ It was established in 2007, during the period of the Second Chechen War, by warlord Doku Umarov. He proclaimed himself to be the 'Emir of the mu-

32 Souleimanov and Ouellette, "The Participation of North Caucasian Jihadists in the Syrian Civil War and its Security Implications."

33 Mark Galeotti, "Chechen 'Jihadist International' Emerges in Syria," Russia Beyond the Headlines, April 15, 2013, https://rbth.com/opinion/2013/04/15/chechen_jihadist_ international_emerges_in_syria_25025.html.

34 Jean-François Ratelle, "North Caucasian Foreign Fighters in Syria and Iraq: Assessing the Threat of Returnees to the Russian Federation," Caucasus Survey 4, no. 3 (2016): 218-238.

35 “Imarat Kavkaz," Kavkazsky Uzel [Caucasian Knot], December 27, 2016, www.kavkazuzel.eu/articles/158730. 
jahideen of the Caucasus,' the 'leader of jihad' and the 'only legitimate power in all the territories, where mujahideen are present,' uniting the militant jamaats. ${ }^{36}$ As of the moment of its formation, the Emirate consisted of six Vilayats (territorial administrative formations): Dagestan, Nokhchicho (Ichkeria), Galgaiche (Ingushetia), Iriston (North Ossetia), Nogai Steppe (Stavropol Territory) and the united valayat of Kabarda, Balkaria, and Karachay. Furthermore, the Caucasus Emirate had an official representative office abroad-the Vekalat-headed by an authorized representative of the mujahideen and the Caucasus Emirate. ${ }^{37}$ However, in 2010, under the Omra ${ }^{38}$ \# 20 Doku Umarov abolished the Vekalat. Furthermore, by 2010, CE was recognized as a terrorist organization both by Russia and the US.

At the same time, already in 2010 the organization had started to suffer from internal fragmentation. By the end 2014, with the death of Doku Umarov (officially announced by the Federal Security Bureau (FSB) in 2014) and the subsequent hassle surrounding the appointment of successive leadership and later their elimination, the Caucasus Emirate headquarters moved several times. In fact, the whole organization had become even more fragmented and, perhaps, even entered a state of decline. Some experts (Roschin, for example) point to the change in terrorist tactics of the CE - notably more suicide bombings, carried out by young men and women, as an indicator of the declining state of affairs of the organization. In Autumn 2014, Zailanabidov (the leader of a militant group operating in the Khasavyurt district in Dagestan) took an oath to Abu Bakr alBaghdadi (leader of IS)..$^{39}$ His example was followed by several other militant leaders, who called upon their 'brothers' to do the same. Importantly, a pledge of allegiance to al-Baghdadi in this context requires the individual to renounce their oath to the CE. These actions further aggravated the fragmentation between North Caucasian militants. Presently in 2017, CE is hardly functional, as most of the leaders of its remaining units in Russia have been neutralized.

Throughout the development of the conflict in Syria, starting from 2011 and 2012, the factions led by North Caucasian FTFs in Syria got caught up in the struggle for control over the Syrian opposition between al-Qaeda and IS. In fact, the factions that had appeared in Syria in the first two years of the conflict were very much linked to the Caucasus Emirate. The first North Caucasian jamaat in Northern Aleppo was under the command of a veteran Chechen fighter known as Khamzat (the first Imarat Kavkaz emir in Syria). This was "effectively an outpost of IK," according to Joanna Paraszczuk. ${ }^{40}$ Generally, the Caucasus Emirate rested its loyalties with al-Qaeda - at least, in the early stages of its operations. CE

36 "Imarat Kavkaz," Kavkaz Uzel.

37 "Imarat Kavkaz," Kavkazsky Uzel.

38 Directive/Order.

39 "Imarat Kavkaz," Kavkazsky Uzel.

40 Joanna Paraszczuk, "1st Imarat Kavkaz Amir in Syria Fought Alongside Gelyaev in Chechnya, Died Fighting Alongside Ahrar," From Chechnya to Syria, July 21, 2016, http://www.chechensinsyria.com/?p=25171. 
differs from IS not only ideologically, structurally, in terms of recruitment and the extent of violence it uses, but also in the manner of operation. It works through what Orkhan Dzemal, a regional journalist, refers to as "night-time government" - a parallel government with a clear military structure, "ruling over people oppressed by the weight of the world." IS, however, adopted a "daytime" approach, calling on entire families to join and start a new life. ${ }^{41}$

Prior to 2015, the leaders of CE would denounce those militants who took an oath to al-Baghdadi, and some of those would later re-instate their loyalties to the Caucasus Emirate. For CE, the absence of charismatic leaders, increased fragmentation within itself, the lack of finances and difficulties in recruitment, combined with the impact of CTOs on behalf of the Russian government, have possibly made the alternative Islamist narrative more appealing, making space for IS presence and power.

Interestingly, CE technically had a 'velayat' in Syria, known as Imarat Kavkaz v Shame. On 8 July, 2015, Salakhuddin Shishani and a group of fighters loyal to CE pledged bay'ah to the new CE emir - Abu Usman Gimrinski (Suleimanov). Abu Usman was killed in August 2015 as a result of a CTO carried out by Russian governmental forces. In December 2015, Salakhuddin was removed as the emir of Imarat Kavkaz v Shame. The organization had later in 2016 engaged in battles in the southern Aleppo countryside alongside Junud al-Aqsa ${ }^{42}$ and al-Nusra. However, it seemed that the majority of the fighters were, in fact, Syrian. ${ }^{43}$

On 23 June 2015, IS declared the formation of a new vilayat in Russia's North Caucasus. This declaration followed a string of formal pledges of allegiance of thousands of militants in the region, echoing those of 2014, thus signifying the decline of Imarat Kavkaz and highlighting the need to assess the extent of ISIS influence in the region. As a result of effective IS propaganda targeting Russia and its neighboring countries, by 2017 Russian had become the third most spoken language in IS, after English and Arabic. There is even an IS magazine, published in Russian - Istok, and a media platform called Furat Media.

\section{For Whom Do the North Caucasians Fight?}

The first North Caucasians in Syria became active around 2012, most of them forming the North Caucasian jamaat (groups). According to some sources there were around 15-17 fighters, and among them such figures as Omar al-Shishani,

41 As quoted in Anna Borschevskaya, "The Islamic State Comes to Russia," Journal of International Security Affairs (Fall/Winter 2015): 27-32, available at https://www.washingtoninstitute.org/policy-analysis/view/the-islamic-statecomes-to-russia.

42 "Jund al-Aqsa," in Jihad Intel's "Database: Identifiers of Designated Islamic Terrorist Organizations," Middle East Forum, http://jihadintel.meforum.org/group/123/jundal-aqsa (21 August 2017).

43 Joanna Paraszczuk, "Arabic-Speaking Katiba Guraba Fighting Under Auspices of IK v Shame in South Aleppo," From Chechnya to Syria, March 10, 2016, http://www.chechensinsyria.com/?p=25028. 
Salakhuddin al-Shishani, and Sayfullakh Shishani. ${ }^{44}$ Omar al-Shishani and Sayfullakh had left to form a new, relatively small group called Katiba Muhajireen, which in 2013 would merge with two others (the Arab Kata'ib Khattab and Jaysh Muhammad) to form Jaish al-Muhajireen wal-Ansar. Khamzat, however, stepped out of CE, and later went to fight alongside Ahrar al-Sham ${ }^{45}$ in Aleppo.

Throughout the development of the conflict in Syria, the number of fighters from the North Caucasus, the rest of Russia and the Commonwealth of Independent States (CIS), rose to around 5,000-7,000. The probable motivations of these FTFs have been mentioned - one of the most important being the wish to fight the Russian State and fight against the al-Assad regime. Yet, who do they fight for? Generally speaking, the fighters can be classified as IS-allied and as alNusra (i.e. al-Qaeda) allied. However, the dynamic is complicated, as throughout the conflict factions have switched alliances due to within-faction dynamics, developments within $\mathrm{CE}$, and the changing relationship between IS and al-Nusra.

\section{Jaish al-Muhajireen wal-Ansar (JMA, The Army of Emigrants and Helpers)}

One of the most prominent jihadi groups with originally large North Caucasian membership is Jaish al-Muhajireen wal-Ansar (JMA, The Army of Emigrants and Helpers). As mentioned above, it was formed as a result of a merger between several other factions, and it was Chechen-led, with about a third of the fighters coming from the North Caucasus. The group played an important role in the civil war. It was involved in capturing strategic infrastructure in the north, and is known for its military prowess, high-profile leadership, and affiliation with alQaeda. Omar al-Shishani was the first leader of the group and maintained ties with CE since the group needed 'authority in Syria,' while Omar needed men. The majority of men arriving in Syria from North Caucasus were under oath to Umarov, and Omar Shishani told them that he was also under oath to the CE leader. According to some sources, he had tried to preserve JMA autonomy from either IS or al-Nusra. ${ }^{46}$ Yet, in March 2013 he pledged bay'ah (allegiance) to IS leader al-Baghdadi, along with some of his men. This caused a split inside JMA many CE loyalists perceived it as 'treason,' while at the same time Omar accused Sayfullakh of theft and takfir, ousting him from JMA. ${ }^{47}$ The majority of Russianspeaking fighters faced a dilemma: either to continue fighting independently, under oath to CE, or to swear bay'ah to the IS leader.

44 Paraszczuk, "1st Imarat Kavkaz Amir In Syria Fought Alongside Gelyaev In Chechnya, Died Fighting Alongside Ahrar."

45 "Ahrar al-Sham," in Mapping Militant Organizations, updated August 5, 2017, http://web.stanford.edu/group/mappingmilitants/cgi-bin/groups/view/523.

46 Joanna Paraszczuk, "Umar Shishani's Biographer Distances Him from Imarat Kavkaz Bayah," From Chechnya to Syria, August 1, 2016, www.chechensinsyria.com/?p= 25200.

47 Joanna Paraszczuk, "Khalid Shishani on Why Sayfullakh Shishani \& Umar Shishani Fell Out," From Chechnya to Syria, August 23, 2016, www.chechensinsyria.com/?p=25233. 
Later, Omar would leave JMA and defect to IS in November 2013, taking many fighters with him. He would become a high-profile commander of a northern battalion with a large Russian-speaking membership. Likewise, when Sayfullakh was ousted, many North Caucasian fighters followed him to join Junud alSham. ${ }^{48}$ JMA in 2014 would join the Ansar al-Din coalition, and later pledge allegiance to al-Nusra. Salakhuddin Shishani was the emir of JMA and reportedly attempted to maintain neutrality between the IS and al-Nusra, and even attempted to facilitate a truce. In June 2015, Salakhuddin Shishani (also the emir of Imarat Kavkaz $v$ Shame) was ousted from JMA, and together with FTFs loyal to him and to CE left to establish the Imarat Kavkaz v Shame. ${ }^{49}$ The same year, some of the Russian Speakers from JMA joined Katiba Sayfullah (an Uzbek-led group, part of al-Nusra) to form Liwa al-Muhajireen, although there is not much information about the group. ${ }^{50}$ Muslim al-Shishani, yet another influential FTF from Georgia's Pankisi Gorge, was the leader of Junud al-Sham, who tried to maintain the faction's independence. However, in 2016 Junud al-Sham dissolved, and Muslim and the majority of North Caucasian fighters joined Ajnad alKavkaz, supposedly also independent from the Caucasus Emirate. ${ }^{51}$ Salakhuddin Shishani and his followers formed in 2016 a new group, Jaysh al-Usrah. ${ }^{52}$ As of 2017, JMA is part of Hayat Tahrir al-Sham-the very recently rebranded alNusra-which claims to have no ties to al-Qaeda. ${ }^{53}$

48 "Jund al-Sham - Syria," Terrorism Research \& Analysis Consortium (TRAC), https://www.trackingterrorism.org/group/jund-al-sham-syria (21 August 2017).

49 Joanna Paraszczuk, "Salakhuddin Shishani Swears Bay'ah to New CE Emir," From Chechnya to Syria, July 9, 2015, http://www.chechensinsyria.com/?p=23921.

50 Joanna Paraszczuk, “'Umar from the Caucasus' is Emir of Nusra's Liwa al-Muhajireen Wal Ansar," From Chechnya to Syria, March 12, 2016, www.chechensinsyria.com/?p= 25032.

51 Joanna Paraszczuk, "Interview \& Letter from Anjad al-Kavkaz Amir Abdul Hakim Shishani," From Chechnya to Syria, February 24, 2017, www.chechensinsyria.com/?p= 25309\#more-25309; and Joanna Paraszczuk, “Anjad al-Kavkaz Don't Have Bay'ha to Caucasus Emirate," From Chechnya to Syria, May 22, 2015, available at http://www.chechensinsyria.com/?p=23771.

52 Joanna Paraszczuk, "Salakhuddin Shishani is Emir of Jaish al-Usrah, Khayrullah Shishani Is His Deputy," From Chechnya To Syria, February 16, 2016, available at http://www.chechensinsyria.com/?p=24678.

53 Hayat Tahrir al Sham (HTS) formed following a merger between Jabhat Fateh al-Sham (al- Nusra), Ansar al-Din Front, Jayish al-Sunnah, Liwa al-Haqq, Nour al-Din al-Zinki Movement on 28 January 2017. In his message from 9 February 2017, HTS leader Abu Jabir insisted that the organization "is an independent entity and not an extension of previous organizations or factions." This is seen as an attempt to further distance the organization from al-Qaeda. See BBC Monitoring, "Tahrir al-Sham: Al-Qaeda's Latest Incarnation in Syria," BBC News, February 28, 2017, https://www.bbc.com/news/ world-middle-east-38934206; Thomas Joscelyn, "Hay'at Tahrir al Sham Leader Calls for 'Unity' in Syrian Insurgency," FDD's Long War Journal, February 10, 2017, https://www.longwarjournal.org/archives/2017/02/hayat-tahrir-al-sham-leadercalls-for-unity-in-syrian-insurgency.php. 
The majority of North Caucasian FTFs reside with IS (especially in view of the effective IS propaganda) and the second largest number - with al-Nusra (now Hayat Tahrir al-Sham). Both organizations have North Caucasians in some of the leadership positions. Those that are loyal to IS often criticize the others (al-Nusra and Imarat Kavkaz-allied) for their 'alleged indecisiveness and nationalism,' while the latter disapprove of IS and their excessive use of violence against civilians.

Regardless of whether the FTFs from the North Caucasus joined the ranks of IS, al-Nusra (now Hayat Tahrir al Sham) or other factions, the reputation of being fierce fighters follows them - they tend to take on a higher death toll than local fighters and are often considered as 'elite.' In addition, many North Caucasians are known for plunging into the front lines with no intent of returning alive. ${ }^{54}$ The degradation of the Caucasus Emirate influenced the dispersion of North Caucasian FTFs on the Syrian battleground. Especially after 2014, many FTFs joined IS. The CE decline also allowed for the emergence of IS in North Caucasus. While it may be used just as a substitute 'brand' by the local militants, IS still has a network for present and future use. Furthermore, the numerous 'independent' and al-Nusra affiliated factions harbor individuals who have been involved in the Syrian conflict for a long time. They have gained experience and connections and are fueled by the motivation to fight the Russian government. Many of them can be expected to pose a threat in the future - either in the Caucasus or in other conflict areas.

North Caucasian leaders such as Omar al- Shishani had frequently been used as the 'face' for IS propaganda in Russian in order to attract more fighters. Furthermore, according to other (non-IS) jihadists, IS propaganda had proven to be extremely effective in attracting youth from the Caucasus region and by 2014 the number had almost doubled. The Europol report also references an article from the Russian daily Novaya Gazeta, in which the author postulates that the FSB actually facilitates the travel of extremists from Chechnya and Dagestan to Syria in order to reduce violence within the Russian Caucasus region. Moreover, there seems to be a propaganda war between IS and non-IS affiliated Russian speaking pro-jihadists (e.g. between IS and al-Nusra), which IS appears to be winning. In a letter written via the Kavkaz Center's Telegram account, Khalid Shishani wrote that the North Caucasian youth is generally oblivious to the true nature of the "pseudo-caliphate (IS)," and "explanations on Al-Insad website... and about scholars of jihad such as Abu Qatada Al-Filistini." 55 He further proposed to step up their own propaganda efforts through the use of various social media accounts with an expectation of receiving constant bans, because "in Chechnya the majority of youth are supporters of IS" and this is the fault of the various emirs,

54 Rao Komar, Christian Borys, and Eric Woods, "The Blackwater of Jihad," Foreign Policy, February 10, 2017, http://foreignpolicy.com/2017/02/10/the-world-first-jihadiprivate-military-contractor-syria-russia-malhama-tactical/.

55 Joanna Paraszczuk, "Khalid Shishani: IS is Winning the Propaganda War in Chechnya," From Chechnya to Syria, April 18, 2016, http://www.chechensinsyria.com/?p=25071. 
himself included. ${ }^{56}$ The members of non-IS affiliated factions, such as Abdul Hakim Shishani and Muslim Shishani gave interviews to different websites, such as Nohchicho, for example. ${ }^{57}$

The means by which pro-jihadist propaganda spreads have improved throughout the evolution of the conflict in Syria. Media platforms have become more 'professional' and have adapted according to the needs of their target audience. A large portion of the material is in Russian, which allows for reaching a very broad audience of Russian-speaking individuals worldwide. Despite the ongoing pro-IS and non-IS propaganda war, the former has been extremely effective to date. As a result, many young North Caucasians become easily radicalized and recruited. Many of them continue to seek a way into IS to the battle ground in Syria, while others carry out attacks in North Caucasus (mostly Dagestan and Chechnya). Of course, al-Nusra and other factions also gain new recruits; however, the majority of North Caucasian FTFs still rests with IS. Furthermore, the existing channels of propaganda aid in establishing networks between jihadists that can be used in the future.

\section{Security Implications of North Caucasian FTFs}

Presently, the rate of incoming FTFs into Syria has decreased. This is a result of increased border controls and high casualties among militant groups, among other reasons. Those that have travelled to Syria and Iraq at the beginning of the conflict, for the large part could not return to the North Caucasus to fight against the Russian government. Typically, these were fighters with combat experience who were known to authorities. These fighters paved the way-for themselves and for the fighters in the years to come-by establishing either their own 'independent' factions like Abdul Hakim Shishani and Muslim Shishani, factions affiliated to $\mathrm{CE}$, or those that would later split and be shaped by the IS - al-Nusra rivalry.

Regardless of which faction they may have chosen to join, these fighters may pose a large security threat not only to Russia, but to neighboring countries, or to future conflict zones. The new combat experience gained and/or refined, training received, established networks and reputation add to their 'danger value' - and therefore their ability to mobilize new recruits. Furthermore, the fact that the Syrian battleground had seen the emergence of Malhama Tactical is dangerous in that it may set a future trend. Due to the fact that the majority of North Caucasian FTFs are guided by the wish to fight the Russian government, they may be seen as 'jihadist international's,' willing to travel to other regions in the future because of the inability to fight in the North Caucasus. Some of the 'independent' factions have a stronger political agenda, which may pose a

56 Paraszczuk, "Khalid Shishani: IS is Winning the Propaganda War in Chechnya."

57 IA Nohchico, "Abdul-Hakim ash-Shishani: We Are Supporting the Action of 23 February," Address by Abdul-Hakim ash-Shishani sent to the media (in Russian), http://nohchicho.com/tribune/abdulhakim-about-23-february/. 
greater danger for the Caucasus and increase their desire to return. In sum, the influence of the war in Syria and specifically the ideological reach of the Islamic State in the North Caucasus is a growing concern, despite the heavy security presence in the region.

\section{Instabilities in North Caucasus}

In the fight against insurgency, terrorism and the militants in North Caucasus, there are at least three types of players: the siloviki (police/law enforcement), the boeviki, also sometimes known as 'lesniye' ('from the woods,' because of their place of hiding), and the 'peregovorshik' (the negotiator between law enforcement and the militants). The latter is a peacemaker of sort, who 'brings people out of the woods' and negotiates certain deals between the police and militants. According to Milashina, journalist of Novaya Gazeta, this is how Russian authorities know who left Russia to fight in Syria and, furthermore, they "are not worried about those who leave, they are worried about those who may return."

It is difficult to find official updated statistics concerning the numbers of returning fighters from Syria or the number of terrorist plots or attacks committed by fighters/insurgents affiliated with IS. The number of fighters who returned to the North Caucasus in 2015, according to some estimates, was around $15-20 \%$ (or as many as 889 individuals). ${ }^{59}$ Likewise, not a lot of concrete information about counter-terrorist measures, operations and progress exists in the public domain. In 2015, according to statements of the FSB, 30 terrorist attacks had been successfully averted and 770 'bandits' ${ }^{60}$ and their accomplices were put on trial. In 2016, the number of averted attacks amounted to 42 . The individuals on trial include those who have been involved in crimes of terroristic nature, among them financing, recruiting new members, and leaving the country with the aim to fight abroad.

The website 'Kavkazsky Uzel' provides a chronology of events in the North Caucasus. According to its information, the intensity of fighting between siloviki (law enforcement, Rosgvardia) and the boeviki (militants/insurgents) had grown.

58 For a summary of the article by Elena Milashina in Novaya Gazeta in English, see Paul Goble, "Novaya Gazeta - FSB Helps Islamists from Russia Go to Syria, Only Worried When They Come Back," The Interpreter, July 31, 2015, www.interpretermag.com/ novaya-gazeta-fsb-helps-islamists-from-russia-go-to-syria-only-worried-when-theycome-back/.

59 In 2015, the Director of FSB Alexander Bortnikov stated that 889 fighters had returned to Russia from Syria and Iraq. See Maksim Solopov, "Russia's Special Services Calculated Hundreds of Fighters Coming Back from Syria and Iraq," RBK (in Russian), December 25, 2015, https://www.rbc.ru/politics/25/12/2015/567bfdfd9a7947a3b3b c7387.

60 'Bandit' has a broader meaning and is a general term to refer to a criminal connected to criminal 'band' or organization. In this case it has been used to denote terrorists, or those individuals involved in terrorist activity. 
In 2016, there were 84 armed clashes, 23 explosions, seven terrorist attacks, and a total of 287 casualties. ${ }^{61}$ By contrast, in 2015, there were 87 armed clashes, 11 explosions, six terrorist attacks, and a total of 258 casualties. ${ }^{62}$ The efficacy of attacks carried out by the boeviki had also grown. In 2015, on average, for every 10 siloviki, the boeviki would lose 35 men, while in 2016, for every 10 siloviki, the boeviki would lose 17 men. This tendency had remained until the present (April 2017). The escalating situation in Chechnya, the failures of the Rosgvardia and the returning fighters from Syria have contributed to sustaining this tendency. As a result of clashes and CTOs in 2016, 162 boeviki were killed (including 22 leaders of the 'bandit underground' ${ }^{63}$ ), and four wounded. These numbers had decreased throughout the past three years, with 174 in 2015, and 249 in 2014. So far in 2017, 17 militants have been killed in Chechnya, and eight in Dagestan. ${ }^{64}$ The casualties for law enforcement officers amount to 97 (32 killed and 65 wounded) in 2016; which is nearly double the number in 2015 (49). Since 2015, in Chechnya alone there have been at least 10 cases of assaults on the siloviki (three in 2017, four in 2016, and three in 2015).

Attacks also took place in Ingushetia, Kabardino-Balkaria and Dagestan. Furthermore, IS is increasingly claiming responsibility for assaults in the region. In August 2016, IS had released a video calling for jihad in Russia; however, Kadyrov, the head of the Chechen Republic, did not take it seriously, stating that IS boeviki have neither the required power nor the capabilities. Nevertheless, already back in 2015 IS took responsibility for the first attacks in the North Caucasus; the assault on the Russian army barracks in South Dagestan and a shooting in Derbent provide examples. Some of the boeviki involved in these attacks were fighters who had returned from Syria. ${ }^{65}$ In 2016, there were another five ISlinked attacks in Dagestan and one in Chechnya. Finally, in 2017 (as of April), IS has been linked to at least four attacks, including an assault on a Rosgvardiya checkpoint at the end of March, and two clashes with jihadists in Chechnya. The

61 "Statistics of Casualties in North Caucasus for 7 years," Kavkazsky Uzel [Caucasian Knot], http://www.kavkaz-uzel.eu/articles/statistika_jertv_2010_2016/ (21 August 2017); "North Caucasus: On the Background of Growing Violence in Chechnya, the Fighters' Activities Became Much More Effective," Kavkazsky Uzel [Caucasian Knot], April 6, 2017, http://www.kavkaz-uzel.eu/articles/300522/.

62 "Statistics of Casualties in North Caucasus for 7 years"; "North Caucasus: On the Background of Growing Violence in Chechnya, the Fighters' Activities Became Much More Effective."

63 'Bandit underground' is used to describe the various networks and organizations of insurgents/militants, considered to be tied to terrorist activity.

64 "Infographics: Statistics of the Casualties in North Caucasus in the First Quarter of 2017 Based on Caucasian Knot's Data," Kavkazsky Uzel [Caucasian Knot], April 17, 2017, http://www.kavkaz-uzel.eu/articles/301176/.

65 "NAC: Two Militant Leaders and a Fighter Returning from Syria Have Been Neutralized in Dagestan," RIA Dagestan, November 29, 2015 (in Russian), www.riadagestan.ru/ news/incidents/nak_v_dagestane_neytralizovany_dva_bandglavarya_i_boevik_vern uvshiysya_iz_sirii/. 
attack that took place in March could be tied to a video released on Youtube a few days earlier entitled the "Council of the military jamaat Ichkeria," which allegedly depicts some of the returning fighters who were part of JMA.

The recent terrorist attack in St. Petersburg on 3 April 2017 (an explosion in the city's underground between two central stops which killed 16 and left around 102 injured) was the first one of such scale since 2013. The suspected suicide bomber is said to have been an ethnic Uzbek born in Kyrgyzstan. He had obtained Russian citizenship in 2011 and had been living and working in St. Petersburg. According to RBC, in December 2016 he was deported from Turkey. ${ }^{66}$ On 25 April 2017, the SITE Intelligence Group stated that Katiba al-Imam Shamil, an al-Qaeda linked group in Syria, claimed responsibility for the attack. ${ }^{67}$ Some experts had also suggested that the perpetrator may have been tied to one of the leaders of CE in Kabardino-Balkaria, who according to the National Antiterrorist Committee (NAC) had been eliminated during a CTO in St. Petersburg earlier in August 2016, together with four other prominent members.

A few points, however, should be kept in mind. The attacks for which IS has claimed responsibility are not necessarily carried out by fighters returning from Syria or Iraq. IS has spread to the North Caucasus and many young people (influenced by IS propaganda, as well as the conditions in the region) become radicalized without having been abroad to fight. The word 'boeviki'-militant/insurgent-provides no distinction between the type or affiliation of the militant (Caucasus Emirate, Islamic State, or any other), and is used synonymously to mean 'terrorist.' CE now barely exists, due to the CTOs carried out in 2016 by government forces, and IS has stepped in to fill the void. At least one attack in Chechnya can be tied to fighters who came back from Syria, and who used to be part of JMA. Another attack in Dagestan is tied to a fighter returning from Syria. Furthermore, many returning fighters have already joined the 'bandit underground,' even though the numbers are unclear.

\section{Dealing with FTFs: Collective Responsibility}

Within the past three years, Russia's legislation on countering terrorism ${ }^{68}$ and ensuring public security have been supplemented with new legislation, including

66 Igor Zalubovin, "The Terrorist's Ghost: Chasing Akbar Dzhalilov Who Blew Up the Underground," Snob, April 12, 2017 (in Russian), https://snob.ru/selected/entry/ 123174.

67 Artem Filipenok and Anjelika Basisini, "A Group Connected to Al-Qaeda Claimed Responsibility for the Terrorist Act in the Underground," RBK, April 25, 2017 (in Russian), https://www.rbc.ru/society/25/04/2017/58ff6c359a7947167d4fdcd4; and SITE Intelligence Group, "Alleged AQ-Linked Group Claims St. Petersburg Metro Bombing," 25, 2017, https://news.siteintelgroup.com/Jihadist-News/alleged-aq-linked-groupclaims-st-petersburg-metro-bombing.html.

68 The relevant laws are listed on the website of the National Antiterrorist Committee, http://nac.gov.ru/zakonodatelstvo/zakony.html. 
those known as the 'Yarovaya Laws. ${ }^{69}$ These have acted to broaden the spectrum of crimes understood as terroristic. They have introduced new clauses such as establishing criminal responsibility for failure to inform of a crime of a terrorist nature, on committing an act of international terrorism, and on monitoring electronic messages. Moreover, they defined new auxiliary measures: regulations for telecommunications and internet provider companies on storing data, and a ban on missionary and extremist activity, among others. Some of these laws are the subject of debate concerning limitations of human rights, and possible unconstitutionalism. ${ }^{70}$ However, they are a direct response to the issue of Russian fighters in Syria and the domestic terrorist situation. The maximum penalty that one can get is incarceration for life. The North Caucasus, however, is understood to live according to slightly different laws.

Precisely how the local North Caucasian authorities deal with fighters returning to the region is shrouded in secrecy and so is not entirely clear. Legally, regional approaches draw upon Russian counter-terrorism legislation (the Federal Criminal Laws of the Russian Federation and other anti-terrorist laws ${ }^{71}$ ) and security services conduct regular CTOs. Of particular interest, however, are the concept of collective responsibility and other measures aimed at the general public.

The principle of collective responsibility in modern times is regarded negatively, since it presupposes holding responsible a group of innocent individuals not affiliated with the crime. It is presently employed in Chechnya for control over the population and, by extension, its repression. As reported by Kavkazsky Uzel, in 2016 through this method (in combination with Kadyrov's active visits to different states in the Middle East, financing of mosques and schools), the influence of the Chechen government is increasingly felt among Chechen diasporas within and outside the borders of Russia. According to human rights defenders Sokiryanskaya, Orlov, Lokshina and Gannushkina, Chechen refugees do not forget that they still have 'pressurable' relatives back in Chechnya, who sometimes serve as a reason to return back to their homeland.

According to Orlov, presently Kadyrov is pushing to legislate the principle of collective responsibility on a federal level - and on various local talk shows one

69 Valeria Zenovina, "The President of the Russian Federation Signed the Set of Antiterrorist 'Yarovaya Laws'," Garant.ru, July 7, 2016 (in Russian), www.garant.ru/news/ 782190/.

70 "Stipulations of the Antiterrorist Legislation, Constraining Citizen's Rights," Monitoring New Russian Laws and Their Implementation in the Field of Civil Rights (in Russian), http://monitoring.mhg.ru/zakon15.

71 Section 208, p. 2 of the Criminal Law of the Russian Federation is very commonly applied to those who have returned from Syria. It refers to incarceration for "participation in an armed entity/formation on the territory of a foreign state with aims contradictory to the interests of the Russian Federation" (translated from Russian). Section 205 , on the other hand, pertains to terrorism. The Yarovaya Laws have caused mass public discontent and have drawn the attention of Amnesty International for alleged violations of human rights. 
would now hear that the principle is a norm (although 'only a couple of years ago it was considered barbaric'). In Chechnya, the main motivations for invoking the principle of collective responsibility, however, are counter-terrorism, countering extremism and radicalism, the fight against insurgency and militants (the socalled 'boeviki'). Russian criminal law does not support collective responsibility. One of the anti-terrorist 'Yarovaya Laws,' ${ }^{72}$ as of 20 July 2016, increases criminal responsibility for crimes of terroristic character (beginning at the age of 14), including non-information about an action (completed or in progress) of terroristic character. ${ }^{73}$ The maximum penalty for withholding information is imprisonment for one year, and it is not applicable to spouses and close relatives; however, they can be held financially responsible for any damage inflicted in a terrorist attack. ${ }^{74}$ Nevertheless, the Russian government typically "turns a blind eye" to Kadyrov's collective responsibility in Chechnya and the rest of the North Caucasus. According to Kadyrov, militants responsible for criminal activity will have their families ousted from the republic, and their houses demolished "to the fundament." 75

Collective responsibility is not only the preferred official strategy, it is seemingly supported by ordinary citizens as well (out of fear of the authorities or otherwise). In December 2016 and January 2017, in response to attacks in Dagestan and Chechnya, governmental forces had carried out mass 'reid' detentions and questionings of relatives and friends of eliminated militants. Around 200 people were reportedly detained, including minors. According to Maaz Bilalov, all of the relatives of militants involved in the attacks in December had been fired from their jobs, and their pensions and social subsidies had not been paid. After the January attacks on Chechen police/Rosgvardiya, some of the relatives of militants endured public penance, sometimes through the use of local media (TV

72 Not all have been presently implemented - some have entered into force on 20 July 2016, while others are to be implemented in 2018.

73 These include obtaining education with the aim of carrying out terrorist activity, involvement in a terrorist network, involvement in a terrorist organization, an act of international terrorism, and several others. For more information see Federal Law N375-FZ of July 6, 2016; http://www.garant.ru/hotlaw/federal/782193/ (in Russian).

74 Peter Roudik, "Russia: Collective Responsibility for Acts of Terrorism," Global Legal Monitor, December 24, 2014, http://www.loc.gov/law/foreign-news/article/russiacollective-responsibility-for-acts-of-terrorism/.

75 This statement was made in December 2014, condemning actions of militants who had attacked local police, killing 14 and leaving others injured. After the claim was made, according to information from human rights center 'Memorial,' in December 2014 around nine houses were burnt down and their inhabitants were ousted from Chechnya. For further information see Elena Milashina, "The Threat to Shoot Someone in the Forehead Is Not Illegal?" Novaya Gazeta, December 13, 2014, https://www.novayagazeta.ru/articles/2014/12/13/62349-ugroza-pustit-pulyu-vlob-ne-yavlyaetsya-chem-to-nezakonnym. 
channels, for example), and were forced to leave their homes in Chechnya. ${ }^{76}$ Moreover, the relatives of the deceased police officers have called for blood feuds. According to the custom, the relatives of a killed individual are obliged to take revenge on the killer or his relatives. Historically, among the peoples of North Caucasus blood feuds had served to regulate public relations, protect family honor and fortune. ${ }^{77}$ There was no 'expiration date' for a blood feud, it should be announced through a 'mediator,' and it targets the perpetrator or his close male relatives. This tradition is not new, yet it had been (semi-) contained through the efforts of Kadyrov himself. Reportedly, in response to threat of blood feuds, all the males of the Baharchiev family have left Chechnya. ${ }^{78}$

On January 8, 2017, a protest against IS and its leader al-Baghdadi was held in Grozny, Chechnya and it gathered approximately 2,000 people, mostly ordinary citizens. Among the speakers were mothers of militants that had joined or were planning to join IS. They publicly asked for forgiveness for their sons' crimes. Parental responsibility had also been discussed - people agreed that parents should harshen methods and improve upon the upbringing of their children. Another speaker involved in the protest was the returning fighter Said Mazhaev. He turned himself in to the authorities upon his return from Syria through Turkey in 2014, and had his initial sentence pardoned as a result of a deal with the authorities - evidently according to which he was to engage in counter-narratives and various forms of anti-IS propaganda work with the youth of the republic. ${ }^{79}$ Thus, Said Mazhaev had frequently appeared at mosques, schools, and universities, in interviews in newspapers and on television channels, and elaborated on the dangers of IS (he had actually fought for JMA, and left Syria before Omar Shishani officially joined IS). Reportedly, Mazhaev actually managed to convince some individuals not to join IS, yet his younger brother was among those involved in the attack in Grozny in December $2016 .{ }^{80}$ The protest against IS ended with the burning of al-Baghdadi's portraits. Other public events that serve as a platform for 'discussing' strategies like collective responsibility are town meetings, frequently held after an attack or clash had occurred.

The aim of such protests is to invoke fear in the population through the realization that there will be consequences for involvement in terrorist activities, including for relatives. The principle of collective responsibility is not new and has

76 Kazbek Chanturiya, "Collective Responsibility in Chechnya; An Ineffective Method of Influence," OC Media, January 19, 2017, http://oc-media.org/collective-responsibilityin-chechnya-an-ineffective-method-of-influence/.

77 "Blood Feuds - How They Kill Today in the Caucasus," Kavkazsky Uzel [Caucasian Knot], December 26, 2017 (in Russian), http://www.kavkaz-uzel.eu/articles/296137/.

78 "Villagers Reported on the Eviction out of Chechnya of the Relatives of a Suspected Fighter," Kavkazsky Uzel [Caucasian Knot], December 26, 2017 (in Russian), http://www.kavkaz-uzel.eu/articles/296137/.

79 Chanturiya, "Collective Responsibility in Chechnya; An Ineffective Method of Influence."

80 Chanturiya, "Collective Responsibility in Chechnya." 
historically been used by local authorities and Russian special services in their fight against insurgency in the North Caucasus. Strong pressure is usually exerted onto all male relatives, "up to second cousins," on the paternal side. This frequently involves disappearances, questioning, beatings and torture. It sometimes also involves the use of relatives as human shields in order to persuade a militant to 'come out of the forest,' or cross over to the side of the government. Despite the fact that collective responsibility is an ineffective strategy in terms of addressing the root causes of underlying social problems (in fact, it fuels them), it is deemed successful by the Chechen authorities.

\section{Concluding Remarks}

The approaches to countering terrorism and extremism in the North Caucasus feed into the already existing social instability, grievances and discontent with authorities in the region. The Russian government should develop softer approaches to counter-terrorism. As a result of years of CTOs and counter-terrorist strategies (including 'collective responsibility') the Caucasus Emirate has practically dissolved and presently seems to be hardly functional. However, this is also due to the increasing influence of IS in the region. IS propaganda successfully targets the North Caucasian (and by extension, Russian) youth, agitating them to walk the path of jihad in Russia or outside of its borders. The number of FTFs from Russia and other CIS states, even though presently decreasing, is high $(5,000-7,000)$ and, according to some reports, Russian Security Forces may have contributed to the outflow of fighters in the past. Even though the numbers of fighters returning from Syria to the region are not exactly known, they could be around $15-20 \%$. Those that have returned are either being prosecuted or incarcerated, have joined underground networks, or their whereabouts are unknown.

The number of IS-affiliated attacks in the North Caucasus has grown, and some of the recent attacks in the region are linked to ex-fighters of JMA and other returnees from Syria. The remaining fighters in Syria and Iraq, and those who still seek to join them on the battleground, pose a threat not only to Russia, but to neighboring countries. Their motivations to fight include fighting the Russian government wherever that is possible. With the current developments of the conflict in Syria, and the deteriorating situation and repression in Chechnya and neighboring republics, those motivations only grow stronger. The first wave of FTFs can be seen as potentially more dangerous, for they have managed to secure and build upon their reputations and expand their experience, skills and networks. They are the ones that have established themselves on the battleground through forming different jamaats, and in one instance a 'jihadist private military company.' The second wave of fighters from the North Caucasus was mostly influenced by IS propaganda, which remains influential in the region despite set-backs for the organization in Syria and Iraq. Regardless of their affiliation, North Caucasian FTFs pose a long-term threat to global security. Given the opportunity, they will most likely fight in the Caucasus, but if unable to return home they may be motivated to strike elsewhere instead. 